\title{
Hubungan Karakteristik Sosial Ekonomi dengan Tingkat Kepuasan Bermukim Pemilik Rumah Sederhana di Perumahan Tamansari Bukit Mutiara Kota Balikpapan
}

\author{
Faridah 1 \\ Diterima : 21 Oktober 2013 \\ Disetujui : 6 November 2013
}

\begin{abstract}
This study was conducted to determine the relationship of socio-economic characteristics with the level of satisfaction in living a simple homeowner in Perumahan Tamansari Bukit Mutiara Balikpapan. The results of the study showed that a simple house is not owned by the people of the lower middle. This is shown on the socioeconomic characteristics of a simple homeowners aged between 35-40 years, S1 educated, worked as private employees with an income of 5 to 7.5 million dollars permonth. Meanwhile, homeowners who are elderly feel less satisfied living in a residential neighborhood because of the lack of activity that involves local people. Simple homeowner satisfaction with their home have been met because the home is already renovation with addition of space that is based on the level of need. Socioeconomic characteristics that influence satisfaction settle the residence include age, education, occupation and number of occupants. Satisfaction simple homeowners against residential neighborhood is met because the residental location of flood -free, guaranteed security and quiet environment. Socioeconomic characteristics that influence satisfaction settled on the environment include residential status, age, education, income and long lived .
\end{abstract}

Keywords: socioeconomic characteristics, satisfaction of living, simple homeowners

\begin{abstract}
ABSTRAK
Penelitian ini dilakukan untuk mengetahui hubungan karakteristik sosial ekonomi dengan tingkat kepuasan bermukim pemilik rumah sederhana di Perumahan Tamansari Bukit Mutiara Kota Balikpapan. Hasil dari penelitian menunjukkan bahwa rumah sederhana belum dimiliki oleh masyarakat menengah ke bawah. Hal ini ditunjukkan dari karakteristik sosial ekonomi pemilik rumah sederhana yang mayoritas berusia antara 35-40 tahun, berpendidikan S1, bekerja sebagai pegawai swasta dengan penghasilan 5 hingga 7,5 juta rupiah perbulannya. Sedangkan pemilik rumah yang berusia lanjut merasa kurang puas tinggal di lingkungan perumahan karena minimnya kegiatan yang melibatkan masyarakat setempat. Kepuasan pemilik rumah sederhana terhadap rumah tinggal sudah terpenuhi karena rumah tipe 36 ini sudah direnovasi dengan melakukan penambahan ruangan berdasarkan tingkat kebutuhan ruang. Karakteristik sosial ekonomi yang mempengaruhi kepuasan bermukim terhadap rumah tinggal meliputi usia, pendidikan, pekerjaan dan jumlah penghuni. Kepuasan pemilik rumah sederhana terhadap lingkungan perumahan terpenuhi karena lokasi perumahan yang bebas banjir, keamanan yang terjamin serta lingkungan yang tenang. Karakteristik sosial ekonomi yang mempengaruhi kepuasan bermukim terhadap lingkungan meliputi status rumah tinggal, usia, pendidikan, penghasilan dan lama menetap.
\end{abstract}

Kata kunci: karakteristik sosial ekonomi, kepuasan bermukim, pemilik rumah sederhana

${ }^{1}$ Dinas Pekerjaan Umum Kota Balikpapan

Kontak Penulis: faridah_99@yahoo.com 


\section{PENDAHULUAN}

Tingginya pertumbuhan penduduk dan migrasi ke kota menjadi faktor meningkatnya kebutuhan rumah tinggal. Setiap orang ingin memiliki rumah sebagai salah satu kebutuhan dasar bagi manusia setelah terpenuhinya pangan dan sandang. Berdasarkan UndangUndang No. 1 Tahun 2011 tentang Perumahan dan Kawasan Permukiman menyatakan bahwa setiap orang berhak untuk hidup sejahtera lahir dan batin, bertempat tinggal dan mendapatkan lingkungan hidup yang baik dan sehat yang merupakan kebutuhan dasar manusia. Kebutuhan rumah tinggal masih dapat terpenuhi saat jumlah penduduk belum banyak dan tanah masih luas. Namun lahan semakin terbatas sementara orang yang membutuhkan rumah jumlahnya terus meningkat sehingga kebutuhan akan rumah tinggal belum dapat terpenuhi.

Untuk memenuhi kebutuhan rumah yang terus meningkat, terdapat program pembangunan perumahan yang dilakukan oleh pemerintah dan swasta. Pemerintah melalui perusahaan pembangunan perumahan (Perumnas) membangun rumah untuk golongan masyarakat berpenghasilan rendah dan menengah. Sementara pembangunan perumahan oleh pihak swasta (developer) diperuntukkan bagi golongan masyarakat yang memiliki pendapatan lebih tinggi. Speare dalam Sumarwan (1994:19) menyatakan bahwa memiliki sebuah rumah dapat memberikan kepuasan bagi pemiliknya. Dengan memiliki sebuah rumah maka seseorang atau sebuah keluarga cenderung untuk bermukim dan sangat kecil kemungkinannya untuk pindah ke lokasi atau tempat lain kecuali jika sudah tidak ada kepuasan terhadap kondisi rumah dan lingkungan sekitarnya.

Masyarakat sebagai penghuni rumah tinggal memiliki karakteristik sosial ekonomi yang berbeda-beda. Bagi masyarakat dengan penghasilan yang besar memiliki peluang yang lebih besar untuk mendapatkan hunian yang sesuai dengan kebutuhan dan keinginan namun tidak demikian halnya dengan masyarakat yang penghasilan rendah. Dengan keterbatasan ekonominya penghuni rumah terpaksa tinggal di suatu lokasi hunian yang tidak sesuai dengan keinginannya atau rumah yang ditempati tidak lagi sesuai dengan norma-norma sosial terkait dengan komposisi penghuni rumah sehingga menimbulkan kesesakan dan rasa tidak nyaman.

Namun terkadang tidak semua keluarga yang bertambah anggota keluarganya serta memiliki perekonomian yang baik akan mencari rumah yang lebih besar dengan lokasi yang lebih baik dan tidak semua yang berpenghasilan rendah akan tetap tinggal. Berdasarkan hal tersebut maka penelitian ini dilakukan dengan pertanyaan penelitiannya adalah "Bagaimanakah hubungan karakteristik sosial ekonomi dengan tingkat kepuasan bermukim pemilik rumah sederhana di Perumahan Tamansari Bukit Mutiara Kota Balikpapan ?"

\section{METODE PENELITIAN}

Metode penelitian yang digunakan dalam penelitian ini adalah metode kuantitatif. Teknik pengumpulan data terdiri data primer dan sekunder. Data primer diperoleh dengan menyebarkan kuesioner kepada sampel yaitu pemilik rumah sederhana yang dipilih secara acak (simple random sampling) sebanyak 146 unit rumah sederhana yang ada di Cluster Kutai Hill, Cluster Berau Hill dan Cluster Mahogany Hill di Perumahan Tamansari Bukit Mutiara Balikpapan. Selain menyebarkan kuesioner, observasi atau pengamatan langsung di lapangan juga dilakukan untuk mengetahui kondisi eksisting mengenai kondisi fisik rumah 
dan sarana prasarana lingkungan perumahan. Data sekunder diperoleh dengan melakukan survei kepada pihak-pihak terkait yaitu pengembang (developer) perumahan serta pihak Rukun Tetangga (RT) untuk mendapatkan data-data pemilik rumah sederhana.

Data-data yang telah diperoleh kemudian diolah dan disusun dalam bentuk frekuensi dan persentase lalu dianalisis dengan menggunakan teknik analisis deskriptif kuantitafif untuk menjelaskan, menguraikan dan menginterpretasikan data-data kuantitatif. Alat analisis yang digunakan di penelitian ini meliputi distribusi frekuensi untuk mengetahui karakteristik sosial ekonomi pemilik rumah sederhana, skala likert dengan 5 (lima) tingkatan untuk mengidentifikasi kepuasan bermukim pemilik rumah sederhana dengan mengukur kepuasan terhadap rumah tinggal dan lingkungannya dan tabulasi silang (cross tabulation) untuk mengkaji hubungan antara karakteristik sosial ekonomi dengan tingkat kepuasan bermukim pemilik rumah sederhana di Perumahan Tamansari Bukit Mutiara Kota Balikpapan.

\section{GAMBARAN UMUM}

Penelitian ini mengambil lokasi di Perumahan Tamansari Bukit Mutiara Kota Balikpapan yang terletak di Kelurahan Gunung Samarinda Kecamatan Balikpapan Utara. Kelurahan Gunung Samarinda memiliki luas wilayah mencapai $5,738 \mathrm{~km}^{2}$ dengan jumlah penduduk sekitar 27.226 jiwa. Secara administrasi Kelurahan Gunung Samarinda berbatasan dengan Kelurahan Batu Ampar, Kelurahan Gunung Bahagia, Kelurahan Sumber Rejo, Kelurahan Damai, Kelurahan Karang Rejo dan Kelurahan Muara Rapak.

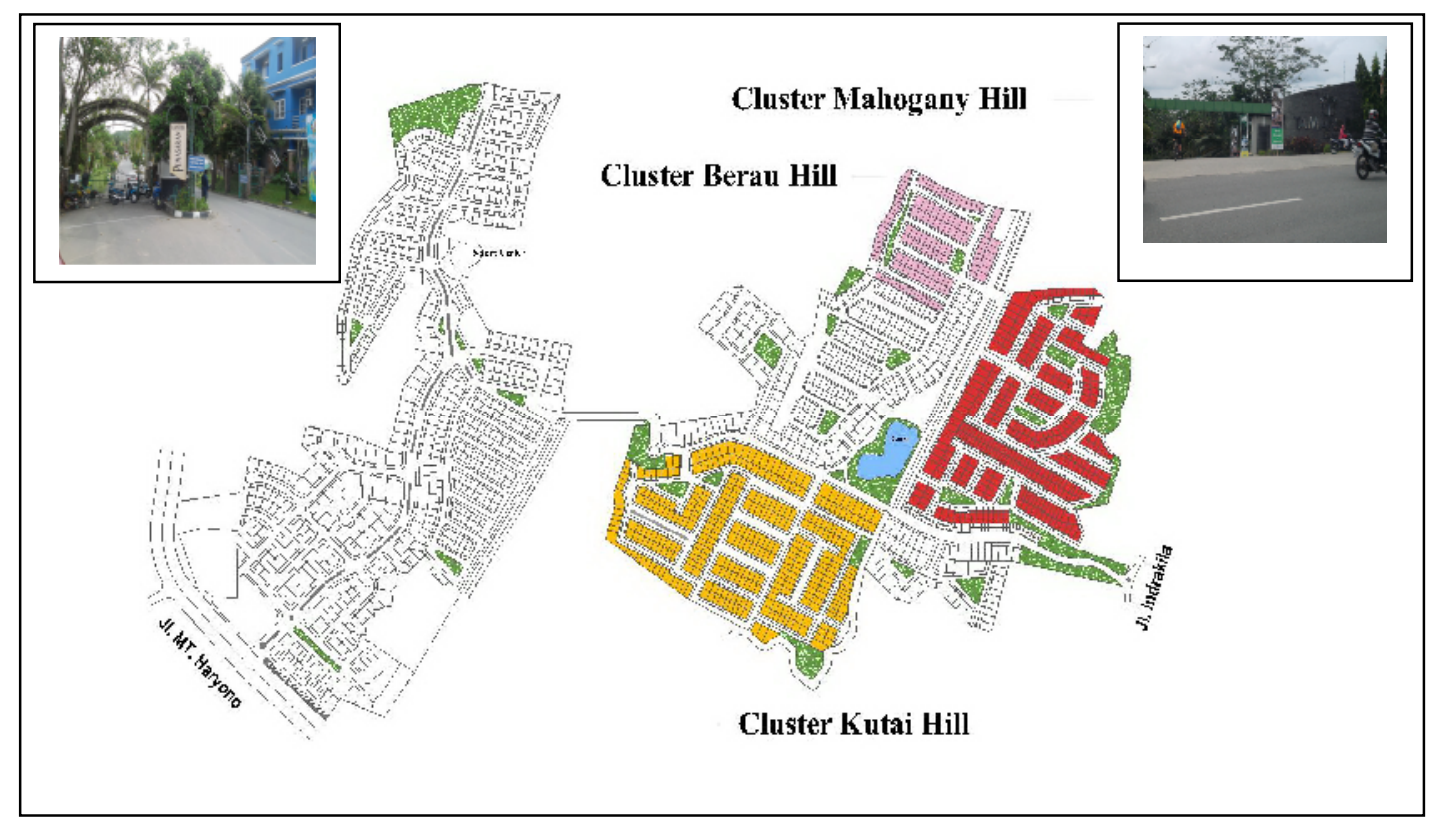

Sumber: Perumahan Tamansari Bukit Mutiara Balikpapan, 2013 
Perumahan Tamansari Bukit Mutiara merupakan salah satu perumahan yang berkembang di Kota Balikpapan. Perumahan ini dikembangkan sejak tahun 1996 dengan luas lahan 49 hektar dan menyediakan 15 hektar untuk penghijauan. Lokasi perumahan ini cukup strategis karena disekitarnya terdapat sekolah, kantor Polda, perkantoran pemerintah, rumah sakit dan pusat perbelanjaan.

Untuk memasuki perumahan ini terdapat dua akses yaitu dari Jl. MT Haryono dan Jl. Indrakila. Rumah tinggal yang ada di perumahan ini di desain bergaya modern minimalis dengan tipe rumah yang beragam mulai tipe 36 hingga tipe 157 dengan total rumah 1168 unit rumah tinggal yang tersebar di 6 (enam) cluster. Untuk rumah sederhana atau rumah dengan tipe 36 terletak di 3 (tiga) lokasi yaitu Cluster Kutai Hill sebanyak 50 unit, Cluster Mahogany Hill sebanyak 115 unit dan Cluster Berau Hill sebanyak 58 unit dengan total 223 unit rumah sederhana.

Prasarana yang ada di perumahan ini meliputi jaringan jalan dengan lebar 8 hingga 10 meter berbahan paving, jaringan drainase berupa gorong-gorong besar di bawah jalan sehingga lokasi perumahan ini cukup aman dari banjir, jaringan air bersih yang bersumber dari PDAM dan WTP, jaringan listrik bersumber dari PLN dengan daya 1300 watt, sampah rumah tangga yang diangkut setiap 2 (dua) hingga 3 (tiga) hari sekali oleh Dinas Kebersihan Pertamanan dan Pemakaman (DKPP). Untuk keamanan, pada akses masuk di tiap cluster terdapat pos jaga dengan 2 (dua) orang penjaga atau security setiap harinya yang akan berkeliling setiap jam. Sedangkan sarana yang tersedia meliputi sport center berupa lapangan tenis dan kolam renang, fasilitas ibadah berupa mesjid serta ruang terbuka atau taman.

Rumah sederhana memiliki luas lahan $90 \mathrm{~m}^{2}$ dan terdiri dari ruang tamu, ruang makan, 2 (dua) buah kamar tidur dengan luas $9 \mathrm{~m}^{2}$ dan KM/WC. Bagian belakang dari rumah sederhana masih tersisa lahan kosong seluas $30 \mathrm{~m}^{2}$ sedangkan lahan di bagian depan dipergunakan untuk carport dan taman. Sehingga jika pemilik rumah sederhana ingin melakukan pengembangan rumah maka dapat dilakukan ke arah belakang rumah tinggal dan secara vertikal dengan menambah jumlah lantai rumah tinggal.

\section{KAJIAN TEORI KARAKTERISTIK SOSIAL EKONOMI DAN KEPUASAN BERMUKIM PEMILIK RUMAH SEDERHANA}

Bertempat tinggal di suatu tempat untuk jangka waktu yang lama bukanlah hal yang mudah. Diperlukan kecocokan antara lokasi dengan tempat tinggalnya dan kondisi rumah tangga penghuninya. Kedua aspek tersebut harus dapat memenuhi harapan dan keinginan manusia sebagai penghuninya. Jika salah satunya tidak terpenuhi maka ada kecenderungan untuk pindah dengan mencari lokasi rumah dan rumah yang lebih sesuai atau yang dapat memenuhi kebutuhan penghuninya (Morris et.al, 1976).

Beberapa hal yang mendorong seseorang atau sebuah keluarga untuk tetap tinggal atau memutuskan untuk bermukim pada suatu lokasi perumahan antara lain adanya kepuasan terhadap rumah dan lingkungannya. Kepuasan terhadap rumah dipengaruhi oleh karakteristik dari tempat tinggal dan rumah tangga penghuninya (Speare dalam Morris et.al, 1976). Beberapa faktor yang menyebabkan adanya perpindahan hunian menurut Rossi dalam Morris et.al, (1976) adalah ketersediaan ruang dalam rumah tinggal, biaya dan kondisi lingkungan sekitar. Apabila aspek-aspek tersebut terpenuhi maka sebuah keluarga cenderung untuk menetap di lokasi huniannya. 
Faktor kepemilikan terhadap hunian juga mempengaruhi kecenderungan orang untuk bermukim (Rossi; Lansing et.al; Speare dalam Morris et.al, 1976). Orang yang menyewa rumah tidak memiliki keterikatan secara langsung dengan huniannya sehingga memiliki kemungkinan untuk pindah atau mencari hunian lain. Berbeda halnya dengan pemilik rumah yang memiliki keterikatan sehingga sangat kecil kemungkinannnya untuk pindah.

Kepuasan terhadap rumah tinggal juga dipengaruhi oleh ketersediaan ruang-ruang yang tersedia sebagai wadah bagi penghuni untuk beraktivitas. Sementara itu siklus hidup sebuah keluarga terus mengalami perubahan sehingga akan terkait dengan kebutuhan ruang di dalam sebuah rumah tinggal. Keluarga muda yang belum memiliki anak belum membutuhkan kamar tidur yang lebih banyak. Namun adanya perubahan komposisi penghuni baik dari jenis kelamin maupun umur maka dibutuhkan kamar tidur baru yang jumlahnya menyesuaikan dengan kebutuhan penghuninya (Sabaruddin, 2003).

Terpenuhinya kebutuhan terhadap ruang-ruang dalam rumah tinggal akan memberikan kenyamanan dalam beraktivitas sehingga penghuni rumah akan merasakan kepuasan terhadap huniannya. Kemampuan untuk melakukan penyesuaian rumah tinggal dengan penghuninya dipengaruhi oleh kondisi rumah dan luasan lahan serta biaya yang harus dikeluarkan. Jika penghuni rumah tidak memiliki kemampuan dari segi ekonomi maka tidak dimungkinkan untuk dilakukan penyesuaian sehingga jika penghuninya yang harus beradaptasi dengan kondisi rumah yang ada akan menimbulkan kesesakan atau kesumpekan yang menimbulkan ketidaknyamanan. Akhirnya ada ketidakpuasan terhadap hunian. namun jika dari segi ekonomi masih memungkinkan sementara lahan tidak mencukupi maka penghuni akan pindah dengan mencari rumah yang lebih besar sehingga kebutuhan terhadap ruang-ruang yang diperlukan akan terpenuhi.

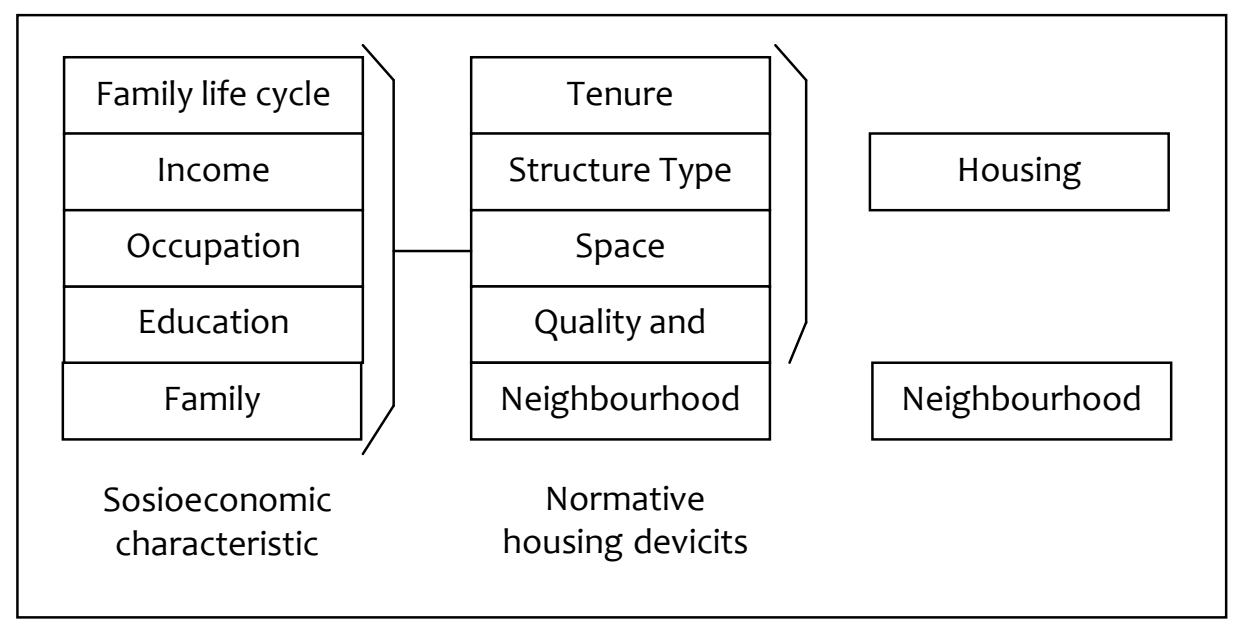

Sumber: Earl W Morris and Mary Winter, 1978

GAMBAR 2 SKEMA KARAKTERISTIK SOSIAL EKONOMI DENGAN KEPUASAN BERMUKIM

Berdasarkan skema diatas, kepuasan terhadap rumah tinggal dipengaruhi oleh faktor kepemilikan rumah, struktur rumah, ruang-ruang di dalam rumah dan kualitas rumah. Dapat memiliki sebuah rumah merupakan suatu kepuasan. Dengan memiliki sendiri, pemilik rumah dapat melakukan perubahan atau perbaikan-perbaikan sesuai dengan kebutuhannya. Kualitas rumah dengan struktur yang baik akan memberikan kenyamanan dan keamanan sehingga penghuni rumah akan dapat beraktivitas dengan baik. Jika rumah yang dimiliki dan 
dihuni sesuai dengan harapan dan keinginan maka akan menimbulkan kepuasan sehingga kecenderungan untuk bermukim di tempat tersebut menjadi lebih besar.

Selain kepuasan terhadap hunian atau rumah tinggal, kepuasan terhadap lingkungan perumahan juga mempengaruhi keputusan seseorang atau sebuah keluarga untuk bermukim di lokasi tersebut. Lingkungan perumahan meliputi lingkungan fisik yaitu sarana dan prasarana perumahan dan lingkungan sosial. Kepuasan terhadap sarana dan prasarana lingkungan perumahan meliputi kondisi jalan, prasarana yang memadai seperti air, listrik, drainase yang baik, keamanan, kebersihan serta berbagai sarana pendukung seperti tempat ibadah, taman bermain, sarana olahraga dll. Selain lingkungan fisik, lingkungan sosial juga mempengaruhi kecenderungan seseorang untuk bermukim di tempat tersebut. Hubungan dengan tetangga, berbagai kegiatan yang ada di masyarakat jika sesuai dengan preferensi bermukim pemilik dan penghuni rumah maka akan menimbulkan kepuasan.

Terpenuhinya kepuasan pemilik penghuni rumah terhadap rumah dan lingkungannya dipengaruhi oleh karakteristik sosial ekonominya. Karakteristik sosial ekonomi ini meliputi pendapatan, pekerjaan, pendidikan, komposisi penghuni dan siklus perkembangan penghuni. Pendapatan yang baik dipengaruhi oleh pekerjaan yang baik. Pekerjaan yang baik akan diperoleh jika pendidikannya juga baik. Namun pendidikan baik belum tentu juga mendapatkan pekerjaan yang sesuai yang akhirnya akan mempengaruhi tingkat pendapatan. Tingginya pendapatan perbulan yang diperoleh sebuah keluarga akan memudahkan untuk mendapatkan rumah yang layak dengan lingkungan yang sesuai dengan preferensi bermukimnya.

Bertambahnya jumlah anggota keluarga serta siklus perkembangannya tentunya membutuhkan ruangan yang lebih besar dengan jumlah yang lebih banyak. Jumlah anak yang bertambah, jenis kelamin anak, usia anak akan mempengaruhi kebutuhan ruang dalam rumah. Anak yang menjelang remaja dengan jenis kelamin yang berbeda membutuhkan kamar tidur terpisah. Kebutuhan ruang tersebut akan dapat terpenuhi jika dimungkinkan untuk dilakukan transformasi terhadap rumah.

Untuk melakukan transformasi atau perubahan terhadap rumah dalam rangka memenuhi kebutuhan ruang dibutuhkan lahan, struktur dan kualitas bangunan yang baik memungkinkan untuk menambah lantai rumah serta ketersediaan biaya. Jika tidak mungkin dilakukan perubahan terhadap rumah tinggal maka pemilik rumah dapat mencari rumah lain yang berukuran lebih besar yang tentunya membutuhkan biaya. Namun jika dana yang ada terbatas sehingga tidak dimungkinkan untuk pindah atau dilakukan perubahan maka penghuni rumah harus melakukan adaptasi terhadap kondisi rumah yang ada.

Dengan demikian dalam menentukan tempat untuk bermukim tergantung dari kondisi fisik rumah, sarana dan prasarana lingkungan serta tujuan dari penghuni dalam bermukim. Apabila semua hal tersebut dapat terpenuhi maka manusia sebagai penghuni akan merasakan kenyamanan dan ketenangan dalam bermukim.

\section{ANALISIS HUBUNGAN KARAKTERISTIK SOSIAL EKONOMI DENGAN TINGKAT KEPUASAN BERMUKIM PEMILIK RUMAH SEDERHANA}

Karakteristik sosial ekonomi pemilik rumah sederhana meliputi usia dan status kepala keluarga, tingkat pendidikan, pekerjaan kepala keluarga dan istri, penghasilan keluarga 
perbulan, jumlah penghuni rumah dan lama menetap. Berdasarkan hasil dari kuesioner yang dibagikan kepada 146 pemilik rumah sederhana di 3 (tiga) cluster menunjukkan bahwa usia kepala keluarga yang terbanyak adalah 35-40 tahun yaitu 75 pemilik rumah atau $51.37 \%$ dengan status menikah sebanyak $99.23 \%$ atau 145 pemilik rumah. Untuk tingkat pendidikan mayoritas pemilik rumah sederhana berpendidikan S1 sebanyak 88,36\% atau 129 pemillik rumah dengan pekerjaan sebagai pegawai swasta dengan persentase 86,30\% atau 126 pemilik rumah. Sementara para istri yang bekerja sangat sedikit yaitu hanya 42 orang dengan pekerjaan sebagai pegawai swasta, pegawai negeri sipil (PNS) dan pedagang atau wiraswasta. Selebihnya sebanyak 103 orang istri atau $71.03 \%$ sebagai ibu rumah tangga. Untuk penghasilan keluarga perbulannya berkisar antara 5-7.5 juta sebanyak 70 keluarga atau $47.95 \%$. Sedangkan yang berpenghasilan kurang dari 5 juta hanya 2 keluarga atau $1.37 \%$. Penghuni terbanyak pada rumah sederhana berjumlah 4 orang yaitu 77 keluarga atau $52.74 \%$ dengan lama menetap 3-6 tahun sebanyak 93 keluarga atau $64.58 \%$.

Berdasarkan hasil identifikasi karakteristik sosial ekonomi pemilik rumah sederhana menunjukkan bahwa rumah sederhana dimiliki oleh masyarakat berpenghasilan menengah ke atas. Harga rumah yang terus meningkat semakin tidak terjangkau oleh masyarakat berpenghasilan menengah ke bawah khususnya rumah-rumah sederhana di lokasi yang dilengkapi dengan berbagai sarana dan prasarana yang baik. Penghasilan yang tinggi berbanding lurus dengan pekerjaan yang baik. Hal ini terlihat dari pemilik rumah sederhana yang mayoritas bekerja sebagai pegawai swasta. Keterbatasan luas rumah dan ruangan pada rumah sederhana menyebabkan rumah ini lebih banyak ditempati keluarga kecil dengan jumlah penghuni tidak lebih dari 4 (empat) penghuni. Jika jumlah penghuni rumah lebih banyak maka pemilik rumah harus melakukan perubahan pada rumah tinggalnya sehingga penghuni rumah masih dapat melakukan aktifitas dengan baik dan nyaman atau mencari rumah lain yang lebih besar sesuai dengan kebutuhan dari para penghuninya.

Tingkat kepuasan bermukim pemilik rumah sederhana akan terpenuhi jika adanya kepuasan terhadap rumah tinggal serta lingkungan sekitarnya. Berdasarkan hasil kuesioner diketahui bahwa rumah sederhana belum dapat memberikan kepuasan bagi pemilik rumah berdasarkan aspek luas lahan yang hanya $90 \mathrm{~m}^{2}$ serta luas rumah sederhana yang berpengaruh pada ketersediaan ruang yang sangat terbatas. Untuk dapat memenuhi kepuasan pemilik rumah maka dilakukan penambahan ruangan sesuai dengan kebutuhan yaitu membuat dapur yang belum tersedia, ruang keluarga dan atau ruang makan. Untuk jumlah dan ukuran kamar tidur anak juga menimbulkan ketidakpuasan bagi pemilik rumah terkait dengan jumlah dan komposisi anggota keluarga. Sehingga untuk penambahan kamar tidur anak, harus dilakukan pengembangan rumah secara vertikal karena keterbatasan lahan.

Kepuasan terhadap lingkungan dirasakan oleh pemilik rumah sederhana terhadap beberapa aspek yaitu sistem drainase yang baik sehingga lokasi hunian ini cukup aman dari banjir, keamanan yang terjamin karena petugas keamanan yang berkeliing setiap jamnya serta lokasi rumah tinggal yang tenang atau jauh dari kebisingan. Sedangkan aspek yang menimbulkan ketidakpuasan pemilik rumah sederhana terhadap lingkungan hunian yaitu pengangkutan sampah yang dilakukan dua hingga tiga hari sekali yang menimbulkan bau tak sedap yang akan mengganggu kenyamanan penghuni rumah tinggal. Minimnya kegiatan masyarakat menyebabkan hubungan antar tetangga kurang begitu akrab yang juga menimbulkan ketidakpuasan bagi pemilik rumah sederhana khususnya pemilik rumah yang berusia lanjut dan sudah tidak bekerja lagi karena pensiun. 
Untuk memenuhi kepuasan bermukim sangat dipengaruhi oleh karakteristik sosial ekonomi dari pemilik rumah sederhana. Karakteristik sosial ekonomi yang mempengaruhi kepuasan bermukim pemilik rumah sederhana terhadap rumah tinggalnya meliputi usia, pendidikan, pekerjaan dan jumlah penghuni dengan aspek kepuasan terhadap rumah tinggal meliputi luas rumah dan tanah, material dan struktur rumah serta jumlah dan ukuran kamar tidur. Usia kepala keluarga yang produktif, dewasa, memiliki pekerjaan dan sudah menikah akan membutuhkan rumah tinggal yang layak sehingga seluruh anggota keluarga dapat melakukan aktifitasnya dengan nyaman. Untuk memenuhi kebutuhan ruang tersebut diperlukan ukuran tanah yang memungkinkan pemilik rumah dapat melakukan pengembangan terhadap rumah tinggalnya sehingga kepuasan terhadap hunian akan tercapai.

Pemenuhan kebutuhan ruang juga dipengaruhi oleh jumlah dan komposisi penghuni rumah tinggal khususnya ruangan yang bersifat privat yaitu kamar tidur. Jumlah anak, usia dan jenis kelamin anak akan mempengaruhi kebutuhan kamar tidur anak baik jumlah maupun ukuran kamar tidur. Pengembangan yang dilakukan terhadap rumah tinggal juga dipengaruhi oleh kekuatan struktur dan material rumah tinggal sehingga rumah dapat dikembangkan secara horisontal atau vertikal. Selain luas tanah, struktur dan material rumah tinggal, ketersediaan biaya akan mempengaruhi kemampuan pemilik rumah untuk dapat melakukan pengembangan terhadap huniannya. Pemilik rumah dengan pekerjaan yang baik akan memiliki penghasilan yang tinggi sehingga mempunyai kemampuan untuk melakukan pengembangan terhadap rumah tinggalnya atau mencari rumah lain yang lebih luas. Dengan terpenuhinya kebutuhan ruang maka kepuasan pemilik rumah sederhana terhadap huniannya akan tercapai.

Karakteristik sosial ekonomi yang mempengaruhi kepuasan bermukim pemilik rumah sederhana terhadap lingkungannya meliputi status rumah, usia, pendidikan, penghasilan dan lama menetap terhadap aspek hubungan dan sikap tetangga, kegiatan masyarakat serta prasarana yang ada seperti air bersih, listrik, drainase, keamanan, kebersihan dan berbagai fasilitas seperti sarana olahraga, ibadah dan rekreasi. Rumah yang dimiliki sendiri dan ditempati oleh pemilik yang sudah berusia dewasa dengan pendidikan yang tinggi dan pekerjaan yang baik tentunya menginginkan sarana dan prasarana yang baik sehingga pemilik rumah merasa nyaman bertempat tinggal di lokasi tersebut. Penempatan berbagai sarana harusnya tidak hanya terpusat pada rumah-rumah dengan tipe besar namun dapat ditempatkan pada beberapa lokasi yang strategis sehingga mudah untuk dijangkau dan dimanfaatkan oleh seluruh pemilik rumah tinggal.

Selain sarana dan prasarana, minimnya kegiatan masyarakat serta hubungan antara tetangga yang kurang akrab menimbulkan ketidakpuasan khususnya pemilik rumah yang sudah berusia lanjut. Kondisi ini sebenarnya dirasakan juga oleh pemilik rumah berusia produktif namun karena aktifitasnya yang banyak dilakukan di luar rumah maka hal ini tidak begitu dirasakan. Sedangkan yang berusia lanjut dan sudah memasuki masa pensiun lebih memilih untuk mencari rumah di lokasi lain yaitu rumah-rumah di lingkungan informal dimana hubungan antar tetangga masih akrab serta masih adanya kegiatan-kegiatan masyarakat seperti pengajian, kerja bakti dll.

Hal ini menunjukkan bahwa tinggal di lingkungan perumahan yang identik dengan sifat individualistis ternyata masih tetap diperlukan adanya interaksi antar penghuninya serta perlunya kegiatan-kegiatan yang melibatkan penghuni rumah tinggal. Adanya kepuasan terhadap rumah tinggal dan lingkungannya menyebabkan mayoritas pemilik rumah 
sederhana memutuskan untuk menetap. Namun jika salah satu aspek kepuasan bermukim tersebut tidak terpenuhi maka pemilik rumah cenderung untuk mencari rumah atau lokasi hunian lainnya sebagai tempat untuk bermukim.

\section{KESIMPULAN}

Kepuasan bermukim pemilik rumah sederhana dipengaruhi oleh adanya kepuasan terhadap rumah tinggal dan lingkungannya serta karakteristik sosial ekonomi pemilik rumah sederhana. Kepuasan yang dirasakan tersebut membuat pemilik rumah cenderung untuk menetap namun jika salah satu aspek kepuasan bermukimnya tidak dapat terpenuhi maka pemilik rumah akan pindah dengan mencari rumah atau lokasi lain yang dapat memenuhi kepuasan bermukimnya. Hal ini sangat dipengaruhi oleh karakteristik sosial ekonomi pemilik rumah. Jika pemilik rumah tidak memiliki kemampuan untuk mencari rumah atau lokasi lain maka pemilik rumah tinggal akan melakukan perubahan pada rumah tinggalnya sehingga kepuasan bermukimnya tetap dapat terpenuhi atau melakukan adaptasi dengan kondisi rumah tinggal serta lingkungan sekitarnya.

Kepuasan bermukim terhadap rumah tinggal dipengaruhi oleh karakteristik sosial ekonomi pemilik rumah sederhana yang meliputi usia pemilik rumah, tingkat pendidikan, pekerjaan dan jumlah penghuni. Rumah tinggal mampu memberikan kepuasan jika kebutuhan ruang penghuninya dapat terpenuhi. Kebutuhan ruang tersebut akan dapat terpenuhi jika pemilik rumah memiliki kemampuan untuk melakukan perubahan pada rumah tinggalnya atau mencari rumah lain yang mampu memenuhi kebutuhan ruang penghuni rumah tinggal.

Karakteristik sosial ekonomi pemilik rumah sederhana yang mempengaruhi kepuasan bermukim pada aspek kepuasan terhadap lingkungan rumah tinggal meliputi status rumah tinggal, usia pemilik rumah, tingkat pendidikan, penghasilan dan lama menetap. Rumah yang dimiliki dan ditempati sendiri oleh pemiliknya dengan tingkat pendidikan yang tinggi serta penghasilan yang baik menginginkan sarana dan prasarana yang baik pula. Lokasi yang bebas banjir, keamanan yang terjamin serta lokasi yang tenang jauh dari kebisingan mampu memenuhi kepuasan bermukim pemilik rumah sederhana. Selain itu sebagai mahluk sosial kegiatan yang melibatkan penghuni rumah tinggal masih tetap diperlukan sebagai sarana bagi pemilik rumah untuk melakukan interaksi dan bersosialisasi dengan tetangga sekitar.

Rumah sederhana yang berlokasi di lingkungan perumahan dengan berbagai sarana dan prasarana mayoritas dimiliki oleh masyarakat berpenghasilan menengah ke atas sehingga peruntukkan rumah sederhana untuk kelompok masyarakat berpenghasilan menengah ke bawah belum tercapai.

\section{DAFTAR PUSTAKA}

Morris, Earl W et.al. 1976. "Housing Norms, Housing Satisfaction and the Propensity to Move." Journal of Marriage and The Family, hal 309-320. Iowa State University.

Morris, Earl W dan Winter, Mary. 1978. Housing, Family and Society. Volume 1. New York: John Wiley \& Sons.

Sabaruddin, Arif et.al. 2003. Perkembangan Perumahan Rakyat, Masa Lalu, Saat Ini dan Masa Mendatang. Bandung: Puskim. 
Sumarwan, Ujang. 1994. "Family and Housing : An Analysis of The Effect of Tenure Status on Propensity to Move (Keluarga dan Perumahan : Suatu Analisis Pengaruh Status Pemilik pada Kecenderungan untuk Berpindah)." Jurnal Media Gizi \& Keluarga XVIII (1) hal 19-28. Fakultas Pertanian. Institut Pertanian Bogor.

Undang-Undang Republik Indonesia Nomor 1 Tahun 2011 tentang Perumahan dan Kawasan Permukiman. 